\title{
INTERPRETATION OF THE FUNCTION OF THE OBELISK OF AUGUSTUS IN ROME FROM ANTIQUE TEXTS TO PRESENT TIME VIRTUAL RECONSTRUCTION
}

\author{
M. Hiermanseder
}

Hietzing Consult, Vienna, Austria - hiermanseder@gmx.net

KEY WORDS: Astronomy, Line of Meridian, Historical Texts, Archeology, Simulation, Virtual World Heritage

\begin{abstract}
:
About the astronomical use of the obelisk of Augustus on Campo Marzio in Rome, which has already been described by Pliny, well known astronomers and mathematicians like Euler, Marinoni or Poleni have given their expert opinion immediately after it's unearthing in 1748. With the prevailing opinion, based on a brief chapter in "Historia naturalis", it would constitute a line of meridian rather than a sundial, the question had been decided for more than 200 years.

In 1976, however, the prominent German archeologist Edmund Buchner established once more the assumption, that the obelisk has been part of a gigantic sundial for the apotheosis of the emperor Augustus. Excavations of the German Archeological Institute in 1980/81, which brought to light parts of the inscriptions of the scale, were taken as a proof of his theory by Buchner.

Since 1990 works by physicists and experts for chronometry like Schütz, Maes, Auber, et.al., established the interpretation as a line of meridian. Recent measurements and virtual reconstructions of the antique situation in 2013 provide valid evidence for this argument as well.

The different approach to the problem mirrors the antagonism between interpretation of antique texts and the assessment of archeological findings in the light of far fledged historical hypotheses.
\end{abstract}

\section{THE OBELISK OF AUGUSTUS ON CAMPO MARZIO (SOLARIUM AUGUSTI)}

Solarium Augusti or Horologium Augusti is the designation of a large astronomical measuring instrument with a ball on a 30meter-high obelisk used as a shade thrower, which was built on the Campus Martius in Rome under Emperor Augustus (63 BC$14 \mathrm{AD})$. It is considered an incomparably large meridian instrument as already described by the contemporary witness Pliny. The piece of meridian line uncovered by the German Archaeological Institute is about $1.6 \mathrm{~m}$ above the original level of the Campus Martius. The complex probably forms a structural unit with the Mausoleum of Augustus, the associated parks and the Ara Pacis and is one of the most important political signs of the power of Emperor Augustus.

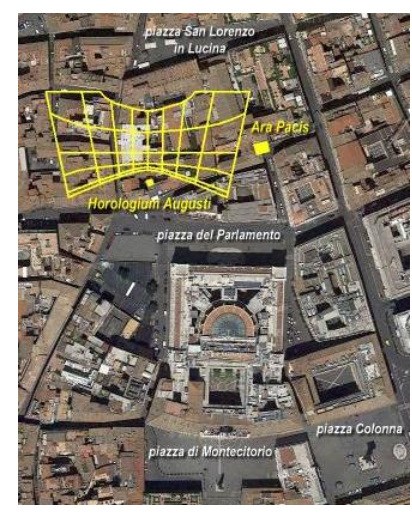

Figure 1: Position of the Solarium Augusti and location of the obelisk in today's Rome

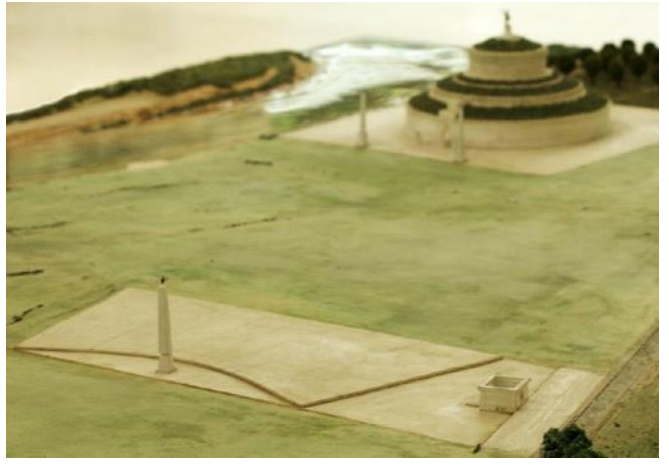

Figure 2.: Model of the antique setting

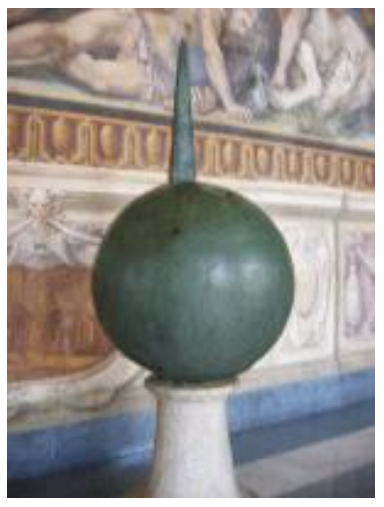

Figure 3: Imperial bronze ball from a Roman obelisk in the Capitoline Museums.

An obelisk with a height of about 30 meters (Obelisco di Montecitorio) from Heliopolis in Egypt, which in $10 \mathrm{BC}$. 
Augustus has mounted, serves as a gnomon. Its addition to a likewise large (at least 200 meters), flat dial to a solar clock has not been proven. The overturned obelisk, broken in five pieces, and its original pedestal were excavated in 1748. About 40 years later, it is reassembled, crowned with a new ball and erected in 1792 with its pedestal at its present location, about 250 meters to the south, in front of the Italian Parliament in Piazza di Montecitorio (Figure 1).

The core shadow of an original, similarly sized (about $75 \mathrm{~cm}$ in diameter) and equally high (about 30 meters) placed ball as Nodus extends about 80 meters. The midday shadow of this globe, to be read on the belonging meridian line, is about 65 meters from the obelisk at the winter solstice in Rome. The line of meridian is made of bronze in the floor slabs and has a length of about 55 meters between the two solstice points. Crossing the Meridian line, longer markers are used as dividing lines between the signs of the zodiac and shorter ones for the 30 degrees division of the signs of the zodiac. The shadow of the sphere thus shows the place of the sun in the zodiac. The section of the meridian line exposed to this day under Via del Campo Marzio no. 48 has a length of $6,60 \mathrm{~m}$, divided by 27 short transverse lines for graduation and 1 long transverse line as a separation between adjacent signs (Figure 14). It is inscribed along the line of meridian with the Greek names of the signs of the zodiac: on the west side it ranges from $19^{\circ}[\mathrm{KRI}]$ OS (Aries) to $16^{\circ}$ TAUR [OS] (Taurus), on the east side, symmetrically to it, of $14^{\circ}$ [ LE] ON (Leo) until $11^{\circ}$ PARTH [ENOS] (Virgin). The degree intervals increase from south to north from $19 \mathrm{~cm}$ to $30 \mathrm{~cm}$. From this, Schütz calculated in 1990 that the shadow-throwing ball crowning the obelisk must have been located about $17.7 \mathrm{~m}$ south of the Leo-Virgin dividing line at a height of about 30 to $31 \mathrm{~m}$. On the long dividing line Leo-Virgin is the Greek inscription ETESIAI PAUONTAI (Figure 12), the Etesia stop. Etesia refers to the regular summer winds (today: Meltemi). At the mark $15^{\circ}$ Taurus is the inscription THEROUS ARCHE, beginning of summer. According to ancient custom, summer does not start with the summer solstice, this is the middle of summer. Summer goes from $15^{\circ}$ Taurus to $15^{\circ}$ Leo. The original site of the Ara Pacis faces the solarium, on the site to the east, between Via in Lucina and Via del Corso, where today the Palazzo FianoAlmagià stands.

\section{ASTRONOMICAL INTERPRETATION IN THE 18TH CENTURY}

The astronomers of the 18th century discuss after 1748 in detail the use of the famous obelisk of Augustus at Campo Marzio (formerly Campo Marzo) in Rome. ${ }^{1}$ Pliny writes: "Ei (obelisco) qui est in Campo, divus Augustus addidit mirabilem usum ad deprehendas solis umbras, dierumque ac noctium ita magnitudines, strato lapide ad magnitudinem Obelisci cui par fieret umbra brumae, consecto die, sexta hora." ${ }^{2}$

\footnotetext{
${ }^{1}$ [Imp(erator)] Caesar divi [f]il(ius) / Augustus / pontifex maximus / imp(erator) XII co(n)s(ul) XI trib(unicia) pot(estate) XIV / Aeg $<\mathrm{y}=\mathrm{U}>$ pto in potestatem / populi Romani redacta / Soli donum dedit // (Emperor Caesar Augustus / son of the deified (Caesar) / Pontifex Maximus / Emperor for the 12th, consul for the 11th, holder of the tribunician power for the 14th time / after Egypt was brought under the rule of the Roman people (this obelisk) of the Sun given as a gift.) CIL 6, 702

2 Plinius, Naturalis historia, Lib 36, c.10. "To the (obelisk), which stands on the field of Mars, the deified Augustus has
}

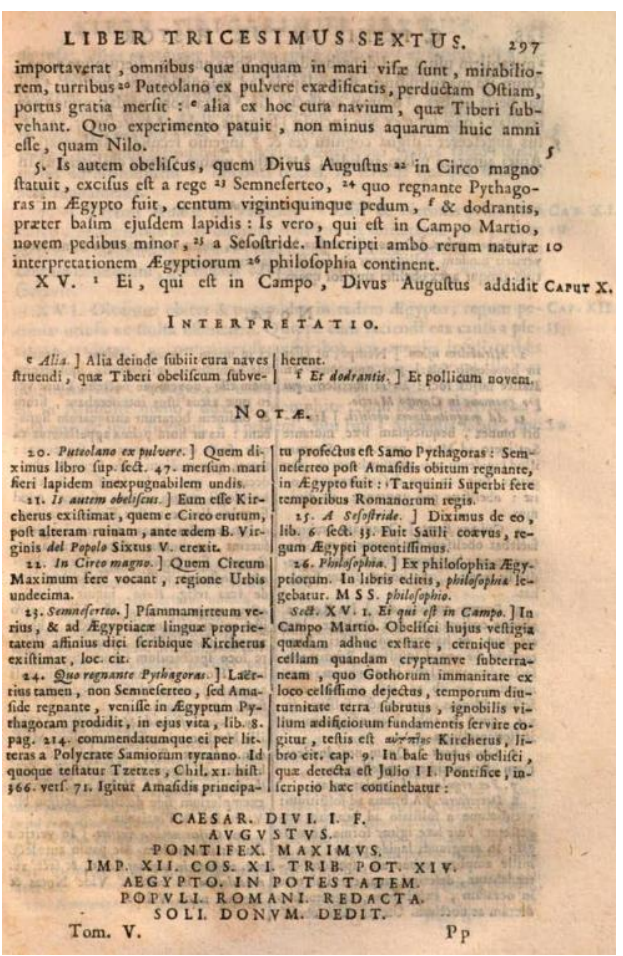

Figure 4: Caii Plinii secundi Naturalis historiae, Liber Tricesimus Sextus, Caput X, S 197

The main points in Pliny, 36th book, 10th chapter, on the obelisk on the Campus Martius are:

- the determination of the length of days and nights by the sun shade of the obelisk (de deprehendas solis umbras, dierumque ac noctium ita magnitudines)

- the golden ball of Manlius, which facilitates observation (ingenio fecundo mathematici, Apici auratam pilam addidit) - the fact that the observations of the solstice have been different from the markings for 30 years, and presumed reasons (Haec observatio triginta iam fere annis non congruit, Solis ipsius dissono cursu, \& caeli aliqua ratione mutato, sive universa tellure aliquid a centro suo dimota, ... sive Urbis tremoribus, ... sive inundationibus Tiberi)

The annotated edition from Paris of 1685 , edited by Jean Hardouin, (S 198, Nota 2) speaks of a use as a sundial (ut esset in horologio solari pro gnomone). The translation of Denso 1765 , just after the description of Bandini and the letters of Marinoni and Euler, already gives the text correctly as a description of the midday line. Only the inserted heading of the tenth chapter ("which serves ... instead of an hour hand"), which is not present with Pliny, is misleading. 


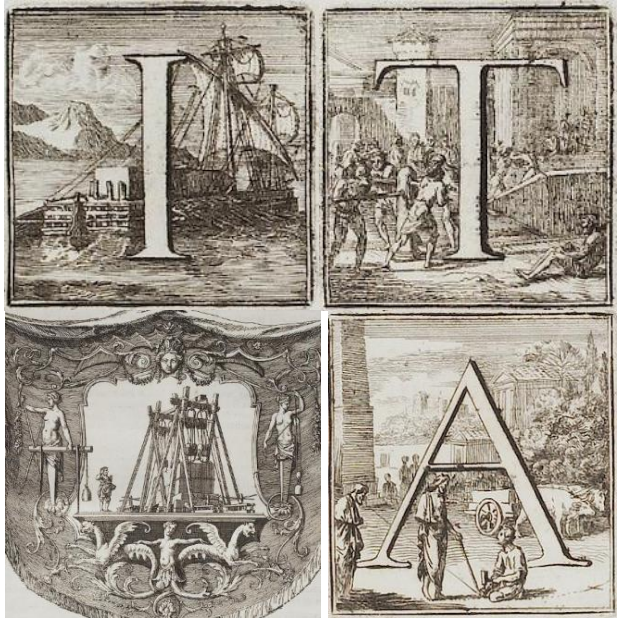

Figure 5: Transport of the obelisk by ship from Egypt, Onward transport, Installation in Rome, Marking of the midday line, initials from Angelo Maria Bandini, Dell'obelisco di Cesare Augusto scavato dalle rovine del Campo Marzo, Roma 1750, Prefazione

That the obelisk was used to determine the midday line and not as a sundial is written by "the most distinguished of the newer mathematicians", ia. Marchese Poleni, Marinoni, Euler, Wolff, ${ }^{3}$ whose letters are printed by the Canon Angelo Maria Bandini, director of the Bibliotheca Medicea Laurenziana in Florence, in a book about the Obelisk in Rome ${ }^{4}$.

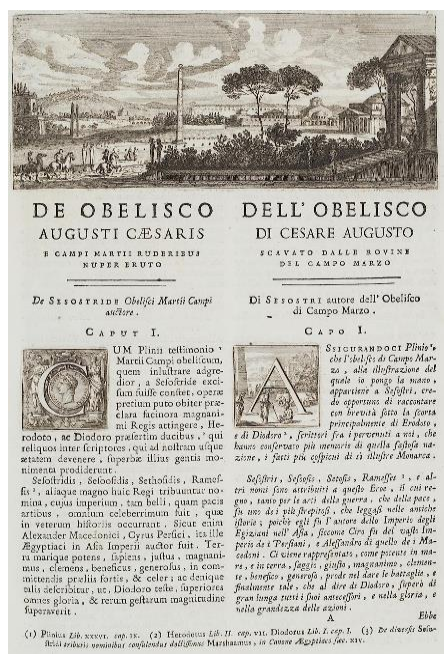

Figure 6: p1, Angelo Maria Bandini, Dell'obelisco di Cesare Augusto scavato dalle rovine del Campo Marzo, Roma 1750

3 At the request of Bandini, his paternal friend Marinoni turns to Euler in February 1749, to Wolff in Halle, to Doppelmayr in Nuremberg to Bose in Wittenberg, to Weidler and Heinsius in Leipzig.

4 Angelo Maria Bandini, Dell'obelisco di Cesare Augusto scavato dalle rovine del Campo Marzo, Commentario di A.M.Bandini, con alcune lettere e dissertazioni di Uomini illustri, Roma 175. The book can be found in No.39 in the Catalogus librorum bibliothecae celeberrimi domini J. Jacobi de Marinoni, $1786 \quad$ ca; http://www.ubs.sbg.ac.at/pdf/AC04548264.pdf

Jagemann Christian Joseph, The History of the Free Arts and Sciences in Italy, Volume 1, Leipzig 1777, p. 270.

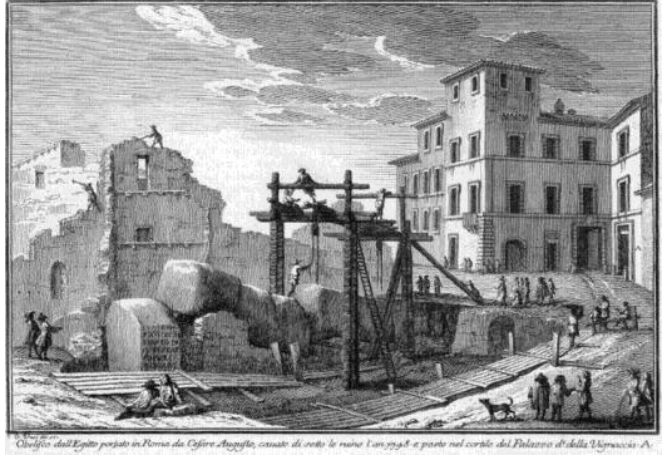

Figure 7: Giuseppe Vasi, Obelisco dall'Egitto portato in Roma da Cesare Augusto cavato di sotte le ruine l'an 1748

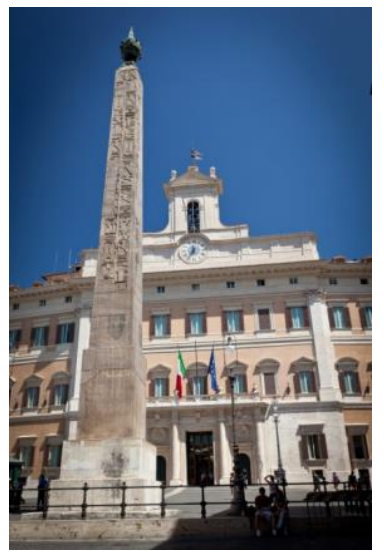

Figure 8: Obelisco di Montecitorio Roma, https://commons.wikimedia.org/wiki/File:Obelisco_di_Monteci torio_Roma_(5251330758).jpg

Marinoni ${ }^{5}$ notes in his letter to Bandini dated November 2, 1748, 8 points to Pliny. Under I., he states that the name is neither sundial nor line of meridian. In II., III. and IV. it is about the height of the obelisk of the pavement and the shadow, which is the longest at the winter solstice at the lowest point of the sun and then daily becomes shorter. Under V. Marinoni writes: "... non requiratur ad signandos horarum numeros ea horologii amplitudo, quae ab umbra per gnomonis verticem projecta requireretur. Proinde quanta, \& quam enormis fieri debuisset extensio strati lapidis ad signandas singulas horas, si per umbras solius verticis Obelisci, vel auratae pilae, quae vertici fuit addita, indicandae fuissent?" ${ }^{6}$ In VI. Marinoni points out that the metal lines on the ground would be perpendicular to the midday line for measuring the shadow length and thus the day and night length and not parallel to it, as is usual for the time display. Also, the golden ball, which should throw an elliptical shadow on the floor, possibly at a temple, speak for the midday line (point VII.). In VIII. Marinoni discusses the astronomical observations in Egypt, further that in 30 years between the expected equinoctium a deviation of 5 hours 36

\footnotetext{
5 Johann Jakob von Marinoni (1676-1755), Imperial court mathematician, astronomer, creator of the Milan Cadastre.

6 ... to indicate the number of hours would not require such a size of clock demanded by the shadow thrown by the head of the gnome. How large and enormous would the extension of the pavement have to be to indicate the individual hours when marked by the shadows of the top of the obelisk, or the golden ball added to the top?
} 
minutes and 30 seconds should occur and closes with the statement: "Omnibus perpensis sententiae eorum accedo, qui meridianae lineae variationsem a Plinio memoratam soli tantum vitio referendam arbitrantur."7

The only original Euler letter to Marinoni ${ }^{8}$, according to the Euler archive, has been kept for almost 270 years in the Biblioteca Marucelliana in Florence, ${ }^{9}$, because Marinoni had sent Euler's letter to his friend Bandini in Tuscany.

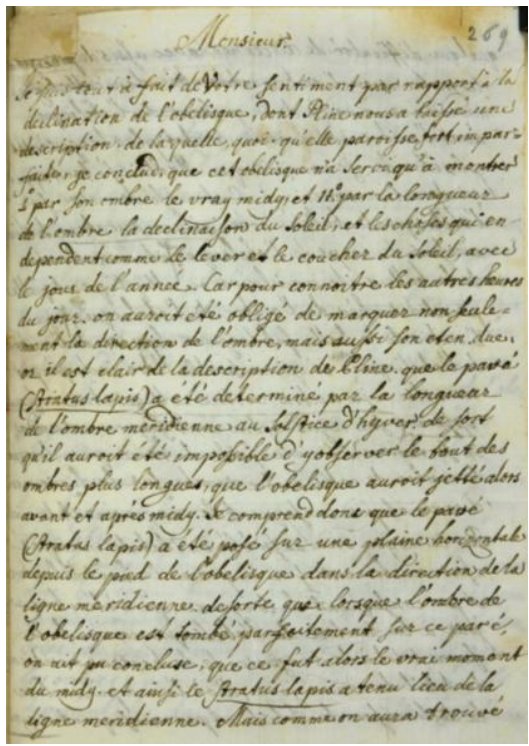

7 "Looking at all these things I agree with those who think that due to the terrain, only the variation of the midday line, as mentioned by Pliny, should be determined." and to underline his opinion Marinoni mentions other prominent supporters of his theory: "The Marquis Poleni, the P.Colombi from Padua, the P.Boscovich in Rome, Mr. Muratori and others are of the opinion that this is a midday line. I agree and here are my reasons..."

8 Juskevic Adolf/Smirnov Vladimir/Habicht Walter, Leonhard Euler Briefwechsel, Beschreibung, Zusammenfassung und Verzeichnisse, Opera Omnia Series Quarta A, Vol.I, S 257.

9 In Florence, the letter without addressee is still believed to be a letter from Euler to Bandini, which does not facilitate his discovery. "Come si evince dal catalogo e dalle notizie ottenute da Manus online, la lettera di Euler a cui lei si riferisce si trova nel carteggio Bandini e, pertanto, essa fa parte della corrispondenza intercorsa tra Euler e Bandini." (Sala Consultazione Manoscritti e Rari, Biblioteca Marucelliana, 20.2.2018) "Credo che questa lettara e stato scritto da Euler a Marinoni e dopo inviato da Marinoni a Bandini chi l'ha stampata nel suo libro Allegato trovate parte del mio manuscritto su questo. "My answer and the reference to the letterhead in Bandini's book has apparently convinced: "grazie per gli interessi dettagli fornitici." see. also "The letter was mistakenly noted by the Florentine officials to A. M. Bandini." Juskevic Adolf / Smirnov Vladimir / Hawk Walter, Leonhard Euler correspondence 1.c. Emil Fellmann already stated in the last century: "... but when I went over the text, it became clear to me that this was not a letter from Euler to Bandini, but to the Viennese astronomer Giovanni Jacopo Marinoni ..." Fellmann Emil, Euler, Marinoni and the sundial of Augustus in Ad Fontes Arithmeticae et algebrae, FS Wolfgang Kaunzner, 1998, p 67.

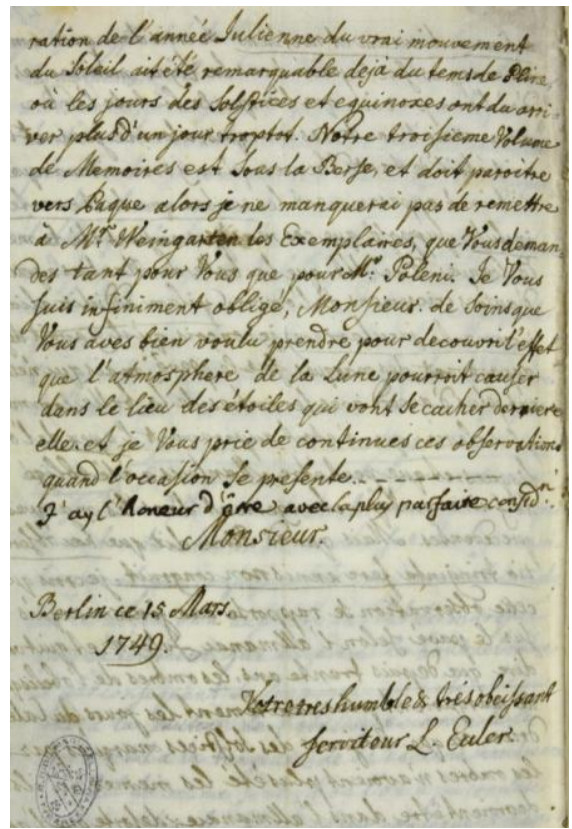

Figure 9: Euler to Marinoni 15.3.1749, Original letter from Biblioteca Marucelliana in Florence, B, B._I.27._IV/22, cc.269270.

Euler agrees with Marinoni on the intended use of the obelisk to determine the midday line. He also relies on the dimension of the shadow and the impossibility due to local conditions to display longer shadows than those at lunchtime on the winter solstice. They also agree on the function of the golden ball. Both astronomers explain the deviations due to the errors of the Julian calendar. ${ }^{10}$

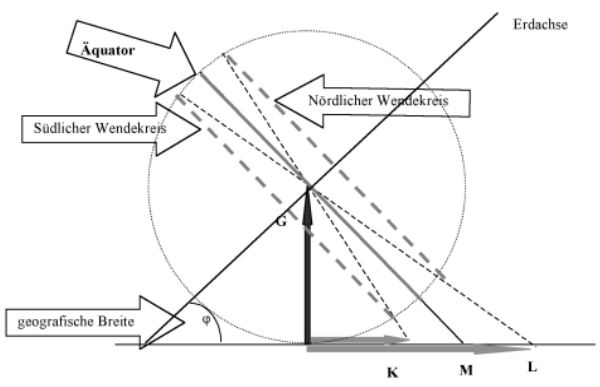

Figure 10: Principle of the gnomon (shadow staff)

The picture shows a model of the earth. The tip of the gnome G is located in the center of the earth, the 3 lines to $\mathrm{K}, \mathrm{M}$ and $\mathrm{L}$ mark the direction of incidence of the sun rays to summer, spring (or autumn) - and winter begins. The line to M marks the

10 "Anyone who might feel disappointed by Euler's" expert opinion "must be aware that nothing better was possible simply because of the Pliny text." The problem was only after the "hard bone work" of the archaeologists (Edmund Buchner) - discovery and exposure of the parts of the dial to master and finally solve with the help of Gnomonic means Euler did not live to see this great moment of 1980/81. " Fellmann Emil, Euler, Marinoni and the sundial of Augustus in Ad Fontes Arithmeticae et algebrae, FS Wolfgang Kaunzner, 1998, p 74. 
equator of the imaginary earth. Normal is the direction of the Earth's axis, the whole sphere is at an angle of latitude. The imaginary sphere appears as a celestial sphere above the viewer. The equator becomes the celestial equator, the earth's axis points to the pole star. Its height gives the latitude. The angles to $\mathrm{K}$ and $\mathrm{L}$ are $23.5^{\circ}$, they mark the ecliptic, the apparent orbit of the sun over the sky in the course of a year. ${ }^{11}$

\section{THE THESIS OF THE ARCHEOLOGIST EDMUND BUCHNER AND IT'S CONFUTATION}

The historian and president of the German Archaeological Institute, Edmund Buchner ${ }^{12}$, put forward the theory in 1976 that the solarium Augusti was a huge sundial. The obelisk as a gnomon cast its shadow over a wide pavement of travertine, the extent of which is calculated to be $160 \times 75 \mathrm{~m}$.

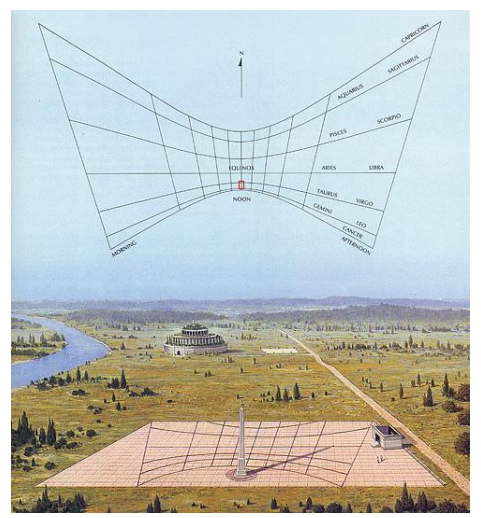

Figure 11: Horologium of Augustus on Campo Marzio according to Buchner

As the day progresses, the shadow travels from west to east along the equinox and north to south along the meridian according to the season, from the winter solstice in Capricorn (the day of the procreation of Augustus and the birth mark of his patron god Apollo) to the summer solstice in Cancer. In the remaining 6 months of the year, the shadow returns to the north. On the autumn equinox (September 23rd), the alleged birthday of Augustus, the shadow of the gnomon falls exactly east and at sunset on the Ara Pacis itself, as a symbol that Augustus is the one born for peace has been.

When Edmund Buchner presents several publications on the Augustan horology from the end of the 1970s, he finds much attention. His ingenious reconstruction fits in well with the renewed interest of research in the topography of Rome and, above all, the design of central areas of the city by Augustus. At that time one speaks of the "power of images" (Paul Zanker) and sees the individual monuments of the self-portrayal of the first princeps, especially the complex on the Campus Martius with Mausoleum and Ara Pacis, as elements of a great "Gesamtkunstwerk". The written tradition of the time offers numerous concrete information about how the ruler connects

11 Rath Gerhard, Astronomie im Physikunterricht, http://www.brgkepler.at/ rath/astronomie/gnomon.html

12 Edmund Buchner (1923-2011), 1969-1979 Professor in Munich, Director of the Commission for Old History and Epigraphics, 1980-1988 President of the German Archeological https://de.wikipedia.org/wiki/Edmund_Buchner the heavenly powers and their appearances with his person and how he enrolls in the course of the civil year through dynastic commemoration and feast days. Why should astronomical time not be spatially fixed as it were, and that the day and the year run be linked to the dynastic monuments? ${ }^{13}$

Due to Buchner's hypothesis, some sondages and excavations are carried out, and in fact one finds a piece of the network of lines mentioned by Pliny. Buchner sees himself confirmed. During the excavations in 1980, he discovers, under a cellar in Via di Campo Marzio, what he thinks is the dial and thus the proof of his sundial.

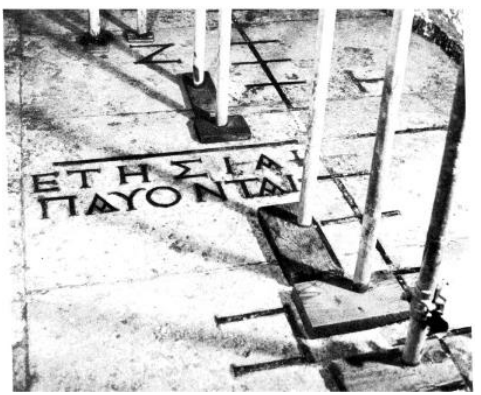

Figure 12: Scale of the meridian, discovered during the German excavation 1980/81 (Zodiac Taurus)

Buchner's main publication, "The Sundial of Augustus", is at first friendly reviewed. However, there remains a certain discomfort, because hardly anyone can understand the mathematical, geometric and astronomical foundations of the highly complicated argumentation and also the supporting findings are rather sparse and by no means unique. Buchner goes on to say that it is "unthinkable" that there is no connection between Ara Pacis and sundial, a classical petitio principii, but which archeologist or historian can and will prove to the renowned president of the German Archaeological Institute errors on the technical level?

In 1990, Tübingen-based physicist Michael Schütz ${ }^{14}$ convincingly argues that Augustus' horology was not a sophisticated sundial, as Buchner claimed, but a meridian line indicating the seasons, indicating the sun's movement through the zodiac signs from solstice to solstice. He proves that Buchner has made wrong calculations and hypotheses have been raised to certainty. Again, the argumentation is very technical in nature and the result is clear: "Buchner's centimeter-accurate forecasts of gnomon height and the location and dimensions of the network are incompatible with the results of the excavation, and his hypotheses on the thematic relationship between the solarium and the Ara Pacis find no support. "

The function of the solarium, just as Pliny writes, is to measure the shadow, "paulatimque per regulas, quae sunt ex aere inclusae, singulis diebus decresceret, ac rursus augesceret" (gradually through scales set in metal, (each) day decreased and grew again). Instead of the imaginary surface of travertine, there

${ }^{13}$ Walter Uwe, Wohin zeigt der Obelisk? Zum Tode von Edmund Buchner, FAZ, 8.9.2011.

14 Michael Schütz, Zur Sonnenuhr des Augustus auf dem Marsfeld, in Gymnasium 97, 1990, S 433, Michael Schütz, Der Obelisk des Augustus, in: Sterne und Weltraum, Jahrgang 27, 1988, p 575f. 
is only a single straight line marking the farthest point of the shadow at midday of the winter solstice (about $50 \mathrm{~m}$ ).

There has long been speculation for a sundial, but also early evidence of the mere existence of a meridian instrument. The renewed interpretation as a sundial is still popular, which is favored by the unusual, successful excavations to 8 meters below today's level. It digs from a small cellar floor about 6 meters deep, that is, far below the foundations of the walls of a multi-storey old house in the densely built-up today's city center of Rome. ${ }^{15}$ There are impressive pictures of this. ${ }^{16}$
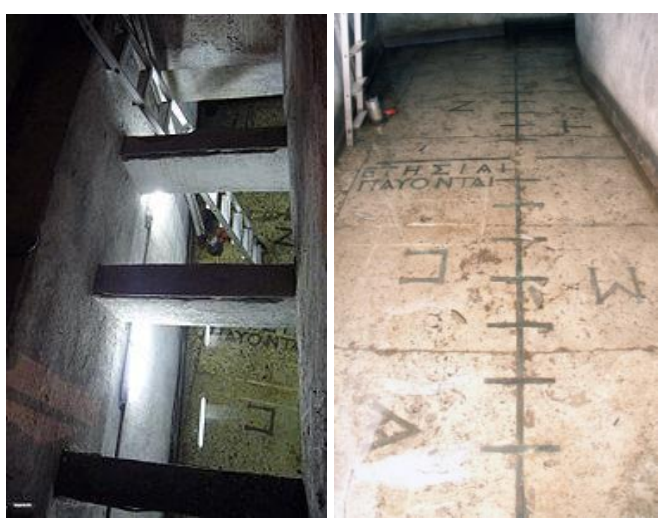

Figure 13: Part of the meridian (looking south) below a cellar in Via di Campo Marzio in Rome

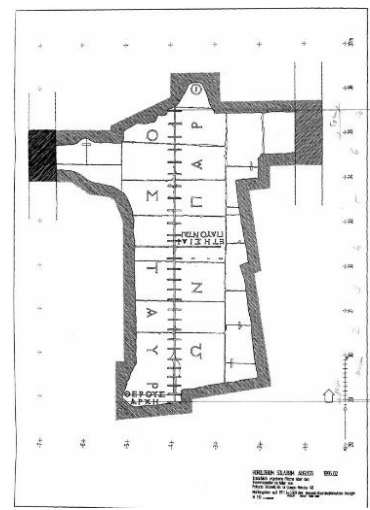

Figure 14: Drawing by Leonhardt (1994)

A sundial and a meridian line both measure the position of the sun's shadow and the length of day and night, but the meridian line only marks the noon (meridianus). When the sun reaches its peak, the shadow falls to the north and gets shorter as the year progresses. At the summer solstice, the longest day of the year, the shadow has moved back the whole meridian line. As the sun declination becomes smaller, the midday shadow lengthens and becomes longer and longer until the winter solstice, the shortest day of the year. With the application of the gnomon and its "shadow tablets", practical astronomy, even in ancient science, becomes a branch of geometry with which later developing trigonometry is connected. ${ }^{17}$

${ }^{15}$ Comparisons of archaeological levels have only been made since the extensive surveying and mapping work by Leonhardt et al. possible.

${ }^{16} \mathrm{https} / / /$ de.wikipedia.org/wiki/Solarium_Augusti

${ }^{17} \mathrm{cf}$. Minow Helmut, Schattenmessung mit dem Gnomon, zfv 4/2005, p $248 \mathrm{ff}$.
The initial interpretation as a sundial can not be sustained, not only for physical reasons (for example, insufficient reach of the Nodus sphere's kernel shadow). There are also significant shortcomings in dealing with old texts.

Argument against Buchner's reconstruction of the horology can be found in Tacitus. Claudius "et pomerium urbis auxit Caesar, more prisco, quo iis qui protulere imperium etiam terminus urbis propagare datur." ${ }^{18}$ (extended the pomerium according to ancient custom, due to which those, who enlarged the empire, were also given the right to extend the city limits.) Half a century before Buchner's excavation, two landmarks (cippi) have been found in the same street, marking the holy city boundary of Rome (pomerium). One is from the time of Vespasian and both are in the western part of the dial. If there had been a pavement made of travertine, that would be it

Buchner also claims that the equinox line of the sundial marked the path of the sunshade as it wandered through the middle of the Ara Pacis on Augustus' birthday. But the excavation of the meridian line has just shown that the obelisk's height and location calculations were wrong. The shadow of the gnomon on the equinoctial line would have become diffused and vanished before it reached the Ara Pacis. In addition, the shadow would have shown each day of the summer months in the direction of the altar.

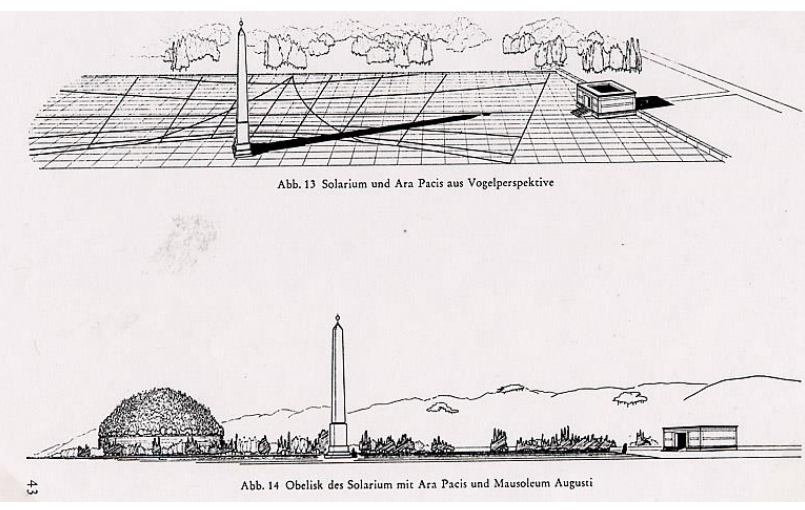

Figure 15: Buchner, Obelisk of the Solarium with Ara Pacis and Mausoleum Augusti

For the theory of science, the matter is interesting. Obviously, there has never been a chance for a dialogue between the disciplines, since the elementary similarities, a hermeneutic interface, are missing. Schütz also competently incorporates the relevant ancient texts, while none of the old erudite scholars find it necessary to seriously reconsider Buchner's reconstruction. After the essay by Schütz, therefore, there is no debate. Buchner publishes two short pertinent contributions, none of them in a central specialized body. In the recent Augustus books, his thesis plays virtually no role. It is occasionally mentioned, but only in parenthesis, with reference to Schütz's objections. ${ }^{19}$

18 Tacitus Publius C., Annales, XII, 23.

19 Walter Uwe, Wohin zeigt der Obelisk? Zum Tode von Edmund Buchner, FAZ, 8.9.2011; Maes Frans, Die Sonnenuhr des Kaisers Augustus. Aufstieg und Niedergang einer Hypothese, in Deutsche Gesellschaft für Chronometrie, 2005. S 168-184 


\section{DIGITAL SIMULATION AND 3D-INTERPRETATION OF OBELISK, LINE OF MERIDIAN AND ARA PACIS}

In 2013, Bernard Frischer of the Virtual World Heritage Laboratory of Indiana University presented his digital simulation and 3D interpretation of the Obelisk, Meridian and Ara Pacis in the period of 9 BC-40 AD. at the Pontifical Academy of Archeology in Rome. ${ }^{20}$

With this method, the exact positions of the sun and its shadow can be displayed at any given time in the specified 50 years and thus the controversy and the theory of Edmund Buchner be considered in a new way. The simulation is based on data from NASA's Horizons System ${ }^{21}$, which contains the apparent orbit taking into account the deviations of the Earth's orbit at the desired time.

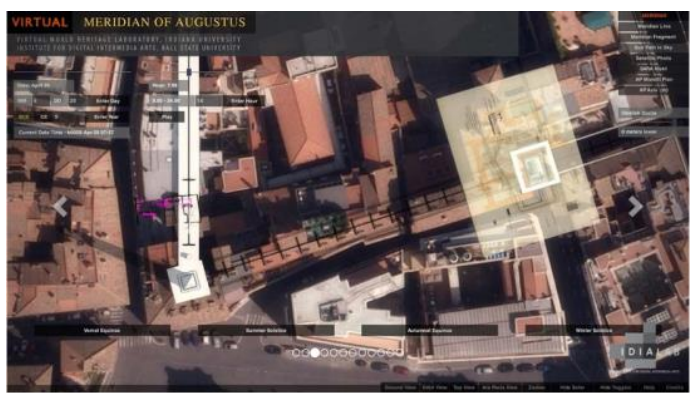

Figure 16: Location of the obelisk, the meridian line and the Ara Pacis in today's urban landscape

The following assumptions are made with reference to the Italian astronomer Auber $^{22}$ : The obelisk has only the function of the gnomon for a meridian line, not for a sundial on a large pavement, for which no proof has been found. The scientific value consists in the determination of the leap years by observatio umbrarum (Pliny) and thus the confirmation of the Julian calendar. ${ }^{23}$ Only the Augusteian phase of the meridian is

20 Frischer Bernard/Fillwalk John, Virtual Meridian of Augustus: Presentation at the Vatican's Pontifical Academy of Archeology, December 19th, 2013, http://idialab.org/virtual-meridian-of-augustus-presentationat-the-vaticans-pontifical-academy-of-archeology/

$21 \mathrm{http} / / /$ science1.nasa.gov/planetary-science/planetary-sciencedata/horizons-system/

22 Auber Paolo Albèri, "L'obelisco di Augusto in Campo Marzio e la sua Linea Meridiana. Aggiornamenti e proposte", Rendiconti della Pontificia Accademia Romana di Archeologia 84, 2011-12, p 447-580.

23 "...il contesto in cui l'Imperatore Augusto diede ordine di sistemare la sfera sull'estremità dell'Obelisco e di tracciare la Linea Meridiana riguardava un problema molto diverso: ad Augusto dobbiamo infatti, in virtù di questo strumento scientifico greco da lui voluto, se il calendario di Giulio Cesare venne finalmente applicato correttamente e potè quindi, per il suo semplice incardinamento con le stagioni valido per secoli e secoli, trasmettersi fino ai nostri giorni e soppiantare, in pratica, tutti gli innumerevoli calendari escogitati da varie culture in tutte le parti del mondo. L'ombra della sfera bronzea sulla sommità dell'obelisco permetteva infatti di verificare che, a seguito di un semplice ciclo di 4 anni, ossia quello che tutti noi conosciamo (tre anni normali e uno bisestile), essa (l'ombra) ritornava a essere proiettata nelle medesime posizioni rispetto $i$ tasselli!" Auber 1.c. secured. The obelisk is brought to Rome after the victory of Augustus in Alexandria 30 BC., the Ara Pacis is planned in 13 $\mathrm{BC}$., the obelisk for the 20th anniversary of the victory in 10 BC. In the following years, the Ara Pacis is added to the meridian line at an unknown time during the reign of Augustus. For later use, there are only hypotheses $\left(\right.$ Buchner, $\mathrm{Rakob}^{24}$ ). The height of the obelisk is 100 Roman feet $(30 \mathrm{~m})$. GPS coordinates and other dimensions for the 3D model of the obelisk, the meridian line and the Ara Pacis have an accuracy of $+/-2 \mathrm{~m}$. The azimuth data comes from the NASA Horizons system. The height of the location is assumed to be $1.58 \mathrm{~m}$.

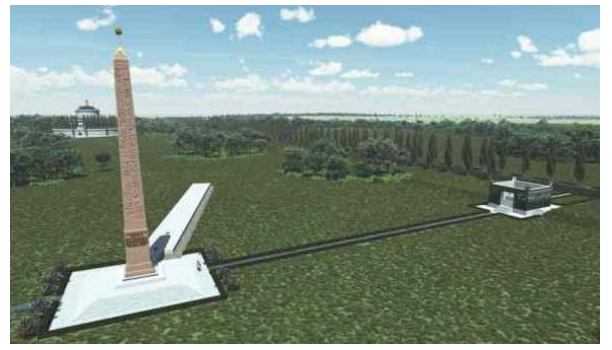

Figure 17: Auber, Obelisk of the Solarium with Ara Pacis and Mausoleum Augusti

The model allows the calculation of different interpretation of the archaeological situation. Thus, the plaster can be represented according to Buchner's hypothesis and the height of the obelisk can be set in units of $1 \mathrm{~mm}$ down to $2 \mathrm{~m}$. The migration of the obelisk shadow on the equinoctial line to the Ara Pacis can be depicted.

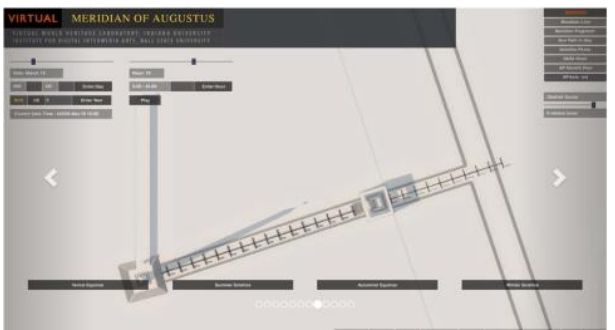

Figure 18: Shadow of the obelisk towards Ara Pacis, 19.3.9 $\mathrm{AD}, 15 \mathrm{~h}$

Through complex calculations, the simulation shows that the shadow does not fall on the Ara Pacis every afternoon of the year, but does not point in the direction of the altar during the winter months from October 30th to February 11th.

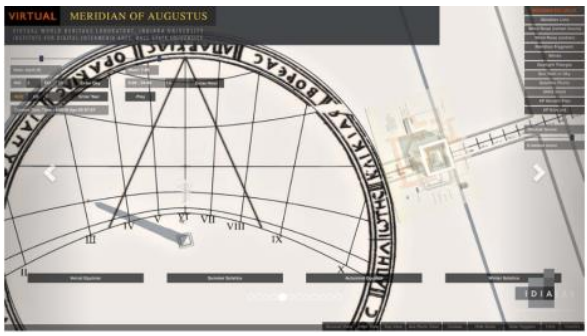

Figure 19: Sundial after Buchner, 20.4.9 AD, 14h

\footnotetext{
${ }^{24}$ Rakob Friedrich, Die Urbanisierung des nördliche Marsfeldes. Neue Forschungen im Areal des Horologium Augusti, Publications de l'École Française de Rome, 1987, p 687-712
} 
The simulation shows that on September 23rd, the shadow moves along the pavement along the equinoxes assumed by Buchner in the direction of the Ara Pacis. However, in the time of Augustus, the fall day-and-night matches fall on the 25th of September of the Julian calendar. Moreover, after Suetonius, Augustus gave name to Sextilis and not his month of birth September, because in this month his first consulate and his biggest victories fall. ${ }^{25}$

\section{COMPARISON OF THE DIFFERENT METHODS OF INTERPRETATION}

The use of the contemporary description by Pliny, even though it requires professional interpretation for its lack of precision, allows, after the excavation of 1748, leading astronomers of the eighteenth century, to define the function of the obelisk of Augustus as the gnomon of a midday line. Even though there are no such sources for every architectural-historical question, the testimony of witnesses who have made themselves available in the historical period is a very secure affair.

Archaeologists want to underpin their theories by excavation finds. It is thus ironic that the eminent German explorer Edmund Buchner refutes his own theses precisely through the sensational findings of the excavation of his German Archaeological Institute under the buildings of the city of Rome. It will find labels of the meridian line, as Pliny describes, but not the huge travertine plaster of Buchner's sundial dial. Decisive for the refutation of Buchner is not a specialist colleague but the physicist Schütz.

Due to the revolution introduced by digital and geoinformation technologies, high-performance tools are increasingly being spread: 3D digitisation (e.g., photogrammetry and scanning), high dynamic range spherical imagery, multispectral sensors, drone photography, virtual and augmented reality, and computer rendering in multiple dimensions. These tools are giving visions and data that are enticing experts with new digital approaches. The role of digital workflows for recording, processing, and disseminating information for the conservation of heritage places have substantially evolved.

Digital simulation and 3D interpretation take advantage of today's databases, calculation methods and graphical possibilities. They show vividly and exactly what is arithmetically possible with the archaeological hypotheses and what is prevented by the local conditions.

\section{REFERENCES}

Auber Albèri, P., "L'obelisco di Augusto in Campo Marzio e la sua Linea Meridiana. Aggiornamenti e proposte", Rendiconti della Pontificia Accademia Romana di Archeologia 84, 201112, p 447-580

Bandini, A.M., Dell'obelisco di Cesare Augusto scavato dalle rovine del Campo Marzo, Commentario di A.M.Bandini, con alcune lettere e dissertazioni di Uomini illustri, Roma 1750

25 "... in cuius ordinatione Sextilem mensem e suo cognomine nuncupavit magis quam Septembrem quo erat natus, quod hoc sibi et primus consulatus et insignes victoriae optigissent."(Sueton, De vita Caesarum, Divus Augustus, 31)
Buchner, E., Die Sonnenuhr des Augustus. Nachdruck aus Römische Mitteilungen 1976 und 1980 und Nachtrag über die Ausgrabung 1980/1981, Mainz 1982

Buchner, E., Neues zur Sonnenuhr des Augustus, in Nürnberger Blätter zur Archäologie, Bd 10, 1993/1994, p 77-84

Fellmann, E., Euler, Marinoni und die Sonnenuhr des Augustus in Ad Fontes Arithmeticae et Algebrae, FS Wolfgang Kaunzner, 1998

Frischer, B.,"From digital illustration to digital heuristics", in Beyond Illustration: 2D and 3D Digital Technologies as Tools for Discovery in Archaeology, BAR International Series 1805, Oxford 2008

Frischer, B./Fillwalk, J., Virtual Meridian of Augustus: Presentation at the Vatican's Pontifical Academy of Archeology 19. Dezember 2013, http://idialab.org/virtual-meridian-ofaugustus-presentation-at-the-vaticans-pontifical-academy-ofarcheology/

Frischer B./Fillwalk, J., "A Computer Simulation to Test the Buchner Thesis. The Relationship of the Ara Pacis and the Meridian in the Campus Martius, Rome", Proceedings of Digital Heritage 2013

Haselberger, L., A debate on the Horologium of Augustus, Controversy and clarifications, with responses by P. J. Heslin and M. Schütz and additional remarks by R. Hannah and G. Alföldy, in Journal of Roman Archaeology, Bd 24, 2011, p 47 98

Haselberger, L./Auber Albèri, P., The Horologium of Augustus: Debate and Context (Journal of Roman Archaeology, Supplementum 99). Portsmouth (Rhode Island) 2014

Heslin, P., Augustus, Domitian and the So-called Horologium Augusti, in The Journal of Roman Studies, Bd 97, 2007, p 1-20

Hiermanseder, M., Aus der Korrespondenz von Johann Jakob von Marinoni mit Leonhard Euler 1736-1751, VGI 2018 (in print).

Hiermanseder, M./König, H., Johann Jakob von Marinoni geadelt und getadelt, Schöpfer des Mailänder Katasters, Kartograph, Wissenschaftler, VGI 2/2017, p 60ff.

Juskevic, A./Smirnov V./Habicht, W., Leonhard Euler Briefwechsel, Beschreibung, Zusammenfassung und Verzeichnisse, Opera Omnia Series Quarta A, Vol.I, Basel 1975

Maes, F., Die Sonnenuhr des Kaisers Augustus. Aufstieg und Niedergang einer Hypothese, in Deutsche Gesellschaft für Chronometrie, Jahresschrift 2005, p 168-184

Minow, H.,, Schattenmessung mit dem Gnomon, zfv 4/2005, p $248 \mathrm{ff}$.

Plinius Secundus Gaius, Naturalis historiae libri XXXVII, Interpretatione et notis illustravit Joannes Harduinus SJ, Tomus 5, Paris 1685

Rakob, F., Die Urbanisierung des nördliche Marsfeldes, Neue Forschungen im Areal des Horologium Augusti, Publications de l'École Française de Rome, 1987, p 687-712

Santana Quintero, M., Harnessing digital workflows for conserving historic places. Int Arch Photogramm Remote Sens Spat Inf Sci XLII-5/W1:9-14, 2017.

Schütz, M.,, Zur Sonnenuhr des Augustus auf dem Marsfeld, in Gymnasium Bd 97, 1990, p 432ff. 